\title{
Male infant patient with a mesenteric cyst in the greater and lesser omenta: a case report
}

\author{
Rocio del Pilar Pereira-Ospina ${ }^{1,2}$, Laura Catherine Montoya-Sanchez ${ }^{1,2}$, Diana María Abella-Morales ${ }^{1,2}$, \\ Javier Yesid Pinzón-Salamanca ${ }^{1,2,3,4,5,6}$, José Miguel Suescún-Vargas ${ }^{1,2,4,5^{*}}$ (D) and Sergio Rueda-Martínez ${ }^{1}$
}

\begin{abstract}
Background: Mesenteric cysts are intra-abdominal masses of congenital origin, which most frequently occur in children, with an incidence of approximately 1 case per 20,000 pediatric admissions. Its progression can be asymptomatic, and its diagnosis can be incidental. However, it usually occurs with symptoms such as nausea, vomiting, constipation, sensation of a mass, and/or diarrhea. The diagnostic imaging method of choice is abdominal ultrasound.

Case presentation: Below, we present the case of a previously healthy 1-year-old male patient with nonspecific symptoms, who was referred to a tertiary hospital. The presence of a mesenteric cyst was detected at the end of the diagnostic approach.

Conclusion: It is important to know these pathologies even though they are infrequent, because although they are benign masses by definition, they can lead to complications such as intestinal torsion, intestinal obstruction, and even peritonitis.
\end{abstract}

Keywords: Cyst, Mesentery, Pediatrics, Abdominal pain

\section{Background}

Mesenteric cysts are intra-abdominal masses which very rarely occur in children (the incidence is lower in children than in adults) [1,2]. The first case was reported in the year 1507 by Benevienal and there have been very few cases reported in the literature since then [3]. The incidence is approximately 1 per 20,000 pediatric admissions [2].

The location of these cysts is more frequent in the mesentery of the small intestine, followed by the mesentery of the colon and the retroperitoneum [4]. Most of these cases are asymptomatic and are detected

* Correspondence: jose.suescun@urosario.edu.co

${ }^{1}$ Instituto Roosevelt, Av. Cra. 4 Este No 17-50, Bogotá 110311, Colombia

2Universidad del Rosario, Bogotá, Colombia

Full list of author information is available at the end of the article incidentally [5, 6]. However, symptoms such as abdominal pain, nausea, vomiting, palpable masses, constipation, or diarrhea may occur $[7,8]$.

The differential diagnoses of this entity include intestinal duplication cysts, diverticulitis, appendicitis, and intestinal obstruction and ovarian, choledochal, pancreatic, splenic or renal cysts. Torsion, rupture, or intestinal obstruction is among the complications that may occur [8-10].

Described below is the case of a previously healthy 1year-old male patient who was referred with a diagnosis of acute diarrheal disease and in whom a mesenteric cyst in the greater and lesser omenta was identified.

C C The Author(s). 2020 Open Access This article is licensed under a Creative Commons Attribution 4.0 International License, which permits use, sharing, adaptation, distribution and reproduction in any medium or format, as long as you give appropriate credit to the original author(s) and the source, provide a link to the Creative Commons licence, and indicate if changes were made. The images or other third party material in this article are included in the article's Creative Commons licence, unless indicated otherwise in a credit line to the material. If material is not included in the article's Creative Commons licence and your intended use is not permitted by statutory regulation or exceeds the permitted use, you will need to obtain permission directly from the copyright holder. To view a copy of this licence, visit http://creativecommons.org/licenses/by/4.0/ The Creative Commons Public Domain Dedication waiver (http://creativecommons.org/publicdomain/zero/1.0/) applies to the data made available in this article, unless otherwise stated in a credit line to the data. 


\section{Case presentation}

The patient is a previously healthy 1 -year-old male patient who was referred to the institution because he had the following clinical symptoms for the past 15 days: multiple diarrheic stools with mucus and without blood (6-7 per day), associated with fever spikes, the highest being $39.8^{\circ} \mathrm{C}$; abdominal distension; and irritability. No additional symptomatology. Physical examination upon admission showed a patient in poor general condition, with marked abdominal distension and a palpable abdominal mass (Fig. 1), decreased bowel sounds, and generalized pain upon abdominal palpation. We decided to hospitalize the patient, with nil by mouth, with a nasogastric tube, and a request for an abdominal ultrasound and paraclinical tests.

The paraclinical tests showed leukocytosis with neutrophilia and thrombocytosis, high CRP $(97.1 \mathrm{mg} / \mathrm{dL})$, mild hyponatremia (Na: $134 \mathrm{mmol} / \mathrm{L}$ ), potassium, chloride, and calcium within a normal range; normal glycemia; kidney function within normal parameters; and coproscopic exam does not show parasitic structures. Abdominal ultrasound shows a multiseptate image which occupies the right half of the abdomen and displaces the bowel loops and could correspond to septate ascitic fluid; distension of intestinal loops. X-ray of the abdomen where displacement of the bowel loops to the left and opacification of the right half of the abdomen is seen (Fig. 2).

Follow-up tests were requested, since the patient presented signs of peritoneal irritation, which found leukocytosis, neutrophilia, and thrombocytosis, PCR (Creactive protein) indicative of bacterial infection; previously requested blood cultures were negative. An exploratory laparotomy was carried out on suspicion of

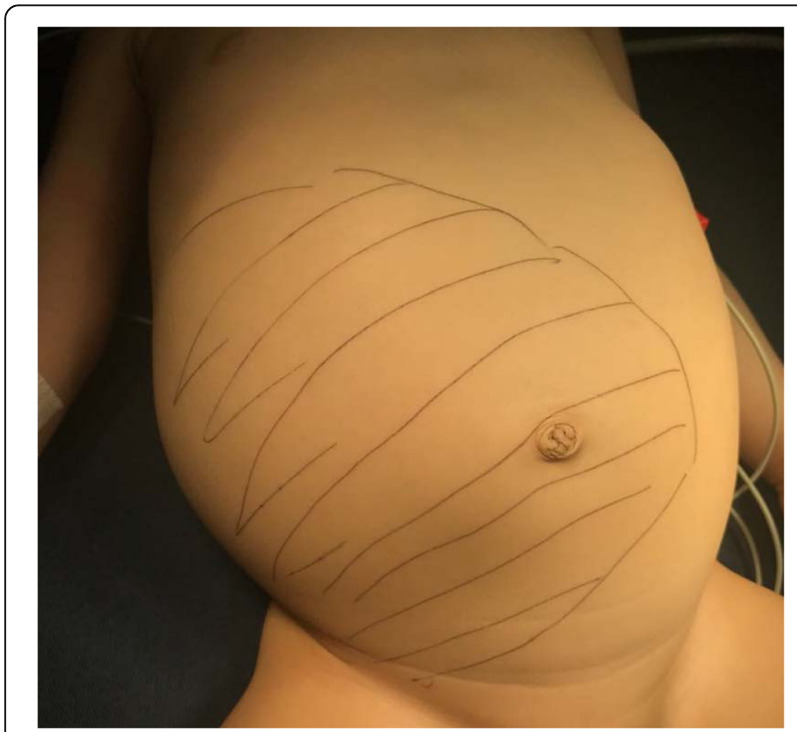

Fig. 1 Delimitation of the abdominal lesion upon palpation

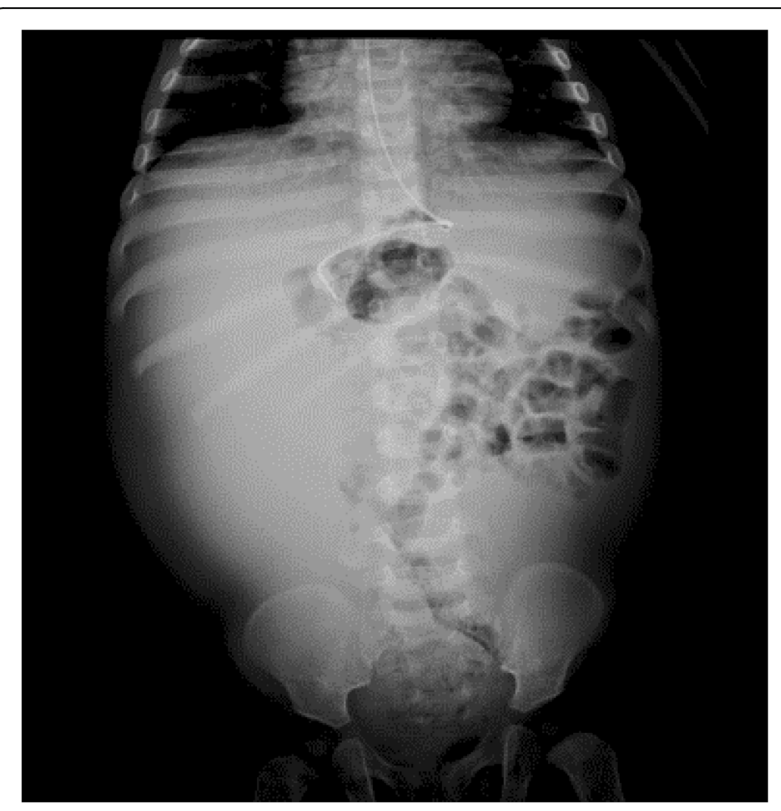

Fig. 2 Bowel loops displaced to the left hemiabdomen, without evidence of hydroaerial levels, distal gas is seen. No extra-peritoneal gas or portal gas is observed. Opacification of the right hemiabdomen. There are no pathological calcifications

sepsis of abdominal origin which found a cystic lesion dependent on the greater and lesser omenta, attached to the greater curvature of the stomach and transverse colon, with greenish-yellow content and whitish particles inside, measuring approximately $30 \mathrm{~cm}$ in diameter and weighing approximately $1 \mathrm{~kg}$ (Fig. 3).

The microscopic description of the pathology showed soft tissues with spaces that appeared to be lymphatic vessels associated with multiple lymphoid aggregates. Septal connective tissue was seen with frequent necrosis. There was no malignancy in this material.

After the postoperative period, the patient adequately tolerated oral administration. The surgical wound was in good condition and progressed adequately, so the patient was discharged with follow-up by pediatric surgery.

\section{Discussion and conclusions}

Mesenteric cysts are benign tumors of congenital origin that predominantly occur during childhood [10]. The most accepted explanation for their etiology is a proliferation of ectopic lymphatic vessels in the mesentery without communication with the lymphatic circulation, which may form anywhere from the mesentery to the retroperitoneum $[8,11]$.

They can be classified into 4 types according to their morphology: type 1 or pediculate, which is easily resectable; type 2 or sessile (between the 2 layers of the mesentery) requires resection of the affected loops and anastomosis; type 3 , which can extend to the 


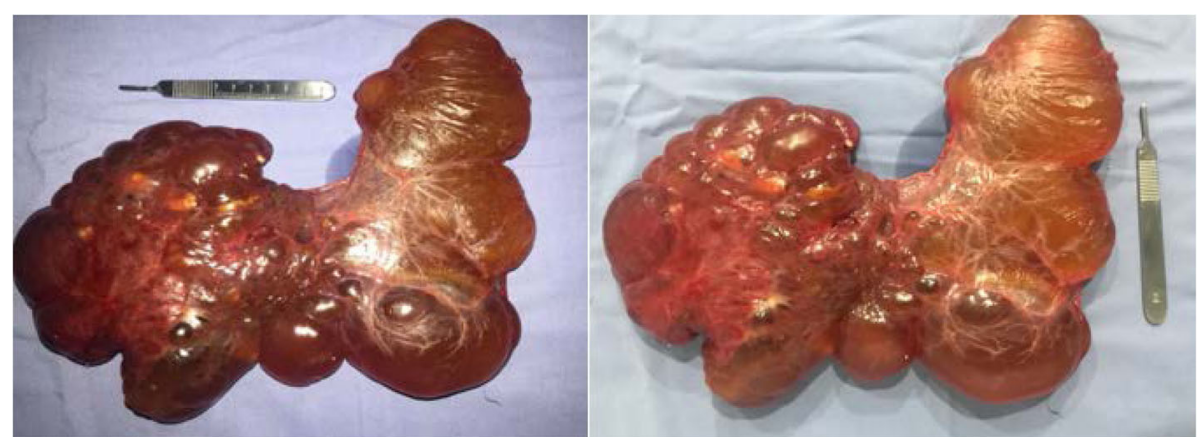

Fig. 3 Cystic lesion measuring $30 \mathrm{~cm}$ in diameter and weighing approximately $1 \mathrm{~kg}$

retroperitoneum and cannot be completely resected; and type 4 , which is multicentric and requires several surgeries and sometimes sclerotherapy $[8,12-15]$.

These lesions can be asymptomatic and this is the reason for the incidental findings. In the case of our patient, the initial diagnostic approach of the remission site was an acute diarrheal disease, due to the multiple diarrheal episodes presented by the patient, and the associated fever; however, a large abdominal mass was palpated during the physical examination, and diagnostic images were requested.

Ultrasonography of the abdomen is the diagnostic imaging of choice, and it is possible to observe a delimited mass with thin walls and cystic appearance. The findings on an x-ray of the abdomen consist of a homogeneous mass with a density similar to that of the water that displaces the intestinal loops. Magnetic resonance and computed tomography do not provide any information in addition to that which was mentioned for the other diagnostic imaging techniques $[8,11]$.

In the case of our patient, abdominal radiography and abdominal ultrasound were performed when an abdominal mass was identified upon palpation, which showed displacement of the intestinal loops to the left and opacification of the right hemiabdomen, and a multiseptate image that occupied the right hemiabdomen and displaced the bowel loops, respectively.

These types of masses must be handled surgically and the resectability of the mass depends on its type. Emergency surgical management was considered in our patient's case, since the patient had abdominal distension associated with symptoms of systemic inflammatory response from the time of admission, and for this reason, sepsis of abdominal origin was considered.

It is important to know these pathologies even though they are infrequent, because although they are benign masses by definition, they can lead to complications such as intestinal torsion, intestinal obstruction, and even peritonitis.

\section{Acknowledgements}

We appreciate the collaboration for the making of this article with the Director of Education and Research of the Instituto Roosevelt.

Availability of data and material

Data sharing not applicable to this article as no datasets were generated or analyzed during the current study.

\section{Authors' contributions}

RP: Performed the data collection, interpretation, and analysis of the clinical case; participated in the writing of the article; and approved the final version sent for possible publication. LM: Participated in the writing of the article and approved the final version sent for possible publication. DA: Participated in the writing of the article and approved the final version sent for possible publication. JP: Analysis of the clinical case, participated in the writing of the article, critical revision of the intellectual content, and approved the final version sent for possible publication. JS: Made important contributions to the idea of the study, analysis of the clinical case, participated in the writing of the article, critical revision of the intellectual content, and approved the final version sent for possible publication. SR: Clinical case analysis, critical review of intellectual content, and approves the final version that is sent for possible publication. All authors read and approved the final version of the manuscript

\section{Funding}

The funding for the publication of this article was provided by the Universidad del Rosario.

\section{Ethics approval and consent to participate}

We have the approval of the ethics and research committee of Instituto Roosevelt, Bogotá, Colombia, for the article publication.

\section{Consent for publication}

We obtain the consent to publish this case report from the parent and legal guardian of our patient.

\section{Competing interests}

The authors declare that they have no competing interests

\section{Author details}

${ }^{1}$ Instituto Roosevelt, Av. Cra. 4 Este No 17-50, Bogotá 110311, Colombia. ${ }^{2}$ Universidad del Rosario, Bogotá, Colombia. ${ }^{3}$ Home Hospitalization Program Instituto Roosevelt, Bogotá, Colombia. ${ }^{4}$ Andes University, Bogotá, Colombia.

${ }^{5}$ Sabana University, Bogotá, Colombia. ${ }^{6}$ Military University, Bogotá, Colombia.

Received: 23 October 2019 Accepted: 26 April 2020

Published online: 11 May 2020

\section{References}

1. Yoon JW, Choi DY, Oh YK, Lee SH, Gang DB, Yu ST. A case of mesenteric cyst in a 4-year-old child with acute abdominal pain. Pediatr Gastroenterol Hepatol Nutr. 2017;20(4):268-72. 
2. Chung MA, Brandt ML, St-Vil D, Yazbeck S. Mesenteric cysts in children. J Pediatr Surg. 1991;26:1306-8.

3. Dequanter D, Lefebvre J-C, Belva P, Takieddine M, Vaneukem P. Mesenteric cysts. A case treated by laparoscopy and a review of the literature. Surg Endosc. 2002;16:1493.

4. Vanek WW, Phillips AK. Retroperitoneal, mesenteric, and omental cysts. Arch Surg. 1984;119:838-42.

5. Karim T, Topno M, Kate M. Simple mesenteric cyst in a child: presentation and management. Arab J Gastroenterol. 2011;12:90-1.

6. Belhassen S, Meriem B, Rachida L, Nahla K, Saida H, Imed K, et al. Mesenteric cyst in infancy: presentation and management. Pan Afr Med J. 2017;26:191 Available from: https:/www.ncbinlm.nih.gov/pubmed/28674584.

7. de Perrot M, Brundler M, Totsch M, Mentha G, Morel P. Mesenteric cysts. Toward less confusion? Dig Surg. 2000;17:323-8.

8. Fernández Ibieta M, Rojas Ticona J, Martinez Castaño I, Reyes Rios P, Villamil V, Giron Vallejo O, et al. Quistes mesentéricos en la edad pediátrica: ¿qué son en realidad? An Pediatría. 2015;82:e48-51 Available from: http://www. analesdepediatria.org/es-quistes-mesentericos-edad-pediatrica-que-articuloS169540331300492X

9. Marte A, Papparella A, Prezioso M, Cavaiuolo S, Pintozzi L. Mesenteric cyst in 11-year old girl: a technical note. Case report. J Pediatr Surg Case Reports. 2013;1:84-6. Available from: http://www.sciencedirect.com/science/article/ pii/S2213576613000225.

10. Prakash A, Agrawal A, Gupta RK, Sanghvi B, Parelkar S. Early management of mesenteric cyst prevents catastrophes: a single centre analysis of 17 cases. Afr J Paediatr Surg. 2010:7:140-3.

11. Ricketts RR. Chapter 89 - Mesenteric and omental cysts. In: Grosfeld JL, O'Neill JA, Coran AG, Fonkalsrud EW, editors. Caldamone AABT-PS (Sixth E), editors. Philadelphia: Mosby; 2006. p. 1399-406. Available from: http://www. sciencedirect.com/science/article/pii/B9780323028424500929.

12. Pampal A, Yagmurlu A. Successful laparoscopic removal of mesenteric and omental cysts in toddlers: 3 cases with a literature review. J Pediatr Surg. 2012;47:e5-8. Available from: http://www.sciencedirect.com/science/article/ pii/S0022346812003272.

13. Memmo L, Belhaj A, Mehdi A. Feasibility of laparoscopic resection of mesenteric cysts: two case reports. Acta Chir Belg. 2013;113:43-6.

14. Solari V, Mullassery D, Lansdale N, Jesudason EC. Laparoscopic excision of a retroperitoneal lymphatic malformation in a newborn. J Pediatr Surg. 2011; 46:e15-7. Available from: http://www.sciencedirect.com/science/article/pii/ S0022346810009218

15. Weeda VB, Booij KAC, Aronson DC. Mesenteric cystic lymphangioma: a congenital and an acquired anomaly? Two cases and a review of the literature. J Pediatr Surg. 2008;43:1206-8.

\section{Publisher's Note}

Springer Nature remains neutral with regard to jurisdictional claims in published maps and institutional affiliations.

Ready to submit your research? Choose BMC and benefit from:

- fast, convenient online submission

- thorough peer review by experienced researchers in your field

- rapid publication on acceptance

- support for research data, including large and complex data types

- gold Open Access which fosters wider collaboration and increased citations

- maximum visibility for your research: over $100 \mathrm{M}$ website views per year

At $\mathrm{BMC}$, research is always in progress.

Learn more biomedcentral.com/submissions 